\title{
外傷性脊髄空洞症の治療経験
}

\author{
岡山労災病院整形外科 \\ 時 岡 孝 光.島田公 雄 \\ 和田山憲・中 山 和 弘
}

\section{Diagnosis and Treatment of Post-traumatic Syringomyelia}

\author{
by
}
Takamitsu Tokioka, Kimio Shimada, Hiroshi Wadayama and Kazuhiro Nakayama
Department of Orthopaedic Surgery, Okayama Rosai Hospital

\begin{abstract}
We report 6 cases of post-traumatic syringomyelia. The mean age at the time of injury was 33.5 years ranging from 18 to 60 years. The paralysis was complete in 5 , and incomplete in one case. Their vertebral fractures were treated surgically except for one case. The duration from injury to diagnosis of syringomyelia ranged from 1.25 to 29 years (mean 7.7 years). The intial symptoms were numbness and/or pain, but 2 cases had no symptoms. All cases showed multi-cystic syringomyelia expanding both rostrally and caudally on MR imaging. 4 patients were treated surgically becase of progression of their symptoms. Laminectomy was performed in 3 cases at the thoracic region, and hemi-open laminoplasty in 2 in the cervical region. They underwent syringo-subarachnoid shunting (one required reoperation due to malfunction of the syringo-peritoneal shunting. Postoperative MR imaging showed the disappearence of the syrinx in one case, significant decrease in 2 , and very slight decrease in one. The patients obtained improvement of symptoms, but the case who required reoperation showed poor recovery of muscle atrophy.
\end{abstract}

Key words : spinal cord injury (脊䯣損傷), post-traumatic syringomyelia (外傷性脊髄空 洞症), syringo-subarachnoid shunting（空洞·くも膜下腔交通術）, operative treatment (手術的治療)

\section{は じめに}


重篤な合併症である．最近経験した 6 例の外傷性脊㵦 空洞症について診断と治療を中心に検討した。

\section{対 象}

対象はこれまで当院で経験した外傷性春髄空洞症の 6 例で，受傷時年齢は 18～59 歳（平均 33.5 歳）であ る. 脊椎の損傷高位は澒椎が 2 例, 胸椎が 2 例, 胸腰 椎移行部が 2 例であり, 完全麻瘦が 5 例, 不全麻痺が 1 例であった（表 1)。これらについて, 臨床像, 画像

表 1 症例一覧

\begin{tabular}{cccccc}
\hline \hline No. & 受傷時年齢 & 性 & 損傷高位 & 初回治療 & 麻痷 \\
\hline 1. & 19 歳 & 男 & L2 & 観血的 & 不全 \\
2. & 60 歳 & 男 & $\mathrm{C} 5$ & 保存的 & 完全 \\
3. & 51 歳 & 男 & $\mathrm{C} 7 / \mathrm{T} 1$ & 観血的 & 完全 \\
4. & 18 歳 & 男 & $\mathrm{L} 1$ & 観血的 & 完全 \\
5. & 26 歳 & 男 & $\mathrm{C} 6$ & 観血的 & 完全 \\
6. & 27 歳 & 男 & $\mathrm{T} 6 / 7$ & 観血的 & 完全 \\
\hline
\end{tabular}

平均 33.5 歳 
診断，治療法とその成績などを検討した.

$$
\text { 結果 }
$$

受傷から診断までの期間は 1 年 3 カ月 29 年（平 均 7.7 年) であった。初発症状は 3 例がしびれで， 1 例が疼痛であり，2 例は無症状であった，麻痷の增悪 は 3 例に認められ，知覚鈍麻が 3 例，筋力低下が 1 例 であった。しびれなどの症状誘発因子として，咳およ びくしゃみが 3 例, 䅡椎伸展が 1 例であった。 また, 上肢腱反射は克進が 1 例，低下が 1 例であった（表 2 ).

MRIでは全例が多房性の空洞を有し，傷害部位よ り頭尾側に拡大していた，空洞の最上端は，延䯑道から 第 4 脳室に及ぶものが 1 例，延髄部までが 2 例であっ た。延髄以上に空洞が及んだ 3 例でも肺活量は正常で あった（図 1).

手術は 4 例に施行した。 shunt 高位は, 胸椎部の Syringo-subarachnoid shunt 術 (以下 S-S shunt) が 2 例, 頝椎部 S-S shunt が 1 例, 初回が胸椎部 Syringo-peritoneal shunt 術 (以下 S-P shunt) で, 再手術が頝椎部の S-S shunt のものが1例であっ

表 2 臨床像

\begin{tabular}{|c|c|c|c|c|c|c|c|}
\hline \multirow{2}{*}{ 症例 } & \multirow{2}{*}{$\begin{array}{l}\text { 受傷から䛦断 } \\
\text { までの期間 }\end{array}$} & \multirow{2}{*}{ 初発症状 } & \multicolumn{2}{|c|}{ 神経学的悪化 } & \multicolumn{2}{|c|}{ 症状誘発 } & \multirow{2}{*}{$\begin{array}{l}\text { 上肢腱 } \\
\text { 反射 } \\
\end{array}$} \\
\hline & & & 知覚 & 筋力 & 咳 & 頚椎伸展 & \\
\hline 1. & 6 年 & 両下肢しびれ & + & + & + & + & 低下 \\
\hline 2 . & 4 年 & 右上肢しびれ & $4-$ & - & - & - & 正常 \\
\hline 3. & 4 年 & 右上肢しびれ & + & - & + & - & 元進 \\
\hline 4. & 29 年 & 左胸部痛 & + & - & + & - & 正常 \\
\hline 5. & 22 年 & - & - & - & - & - & 正常 \\
\hline 6 . & 1 年 3 力月 & - & - & - & - & - & 正常 \\
\hline
\end{tabular}

(平均 7.7 年)

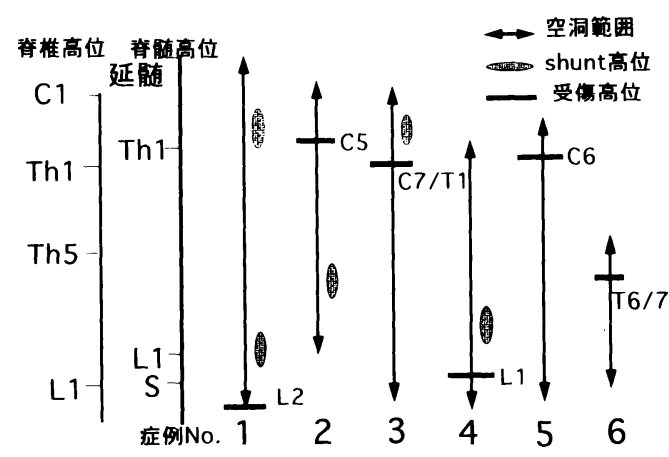

図 1 受傷高位と空洞の拡大範囲
た.

手術成績は，MRIで空洞がほほ消失したものが 1 例, 著明な縮小が 2 例, わずかな縮小が 1 例であった. shunt の設置を脊髄損傷部位より尾側にした 1 例では 頭側の空洞の縮小がやや不十分であった，臨床症状は 全例軽減または消失したが, 再手術の 1 例では脊髄は 菱縮し，麻㾇が残存した（表 3 ).

\section{症例}

症例 1. L2 破裂骨折（不全麻㾝），男性

19 歳のとき，バイクで転倒し受傷したＬ２２破裂骨 折, 不全麻瘦であり, 前方固定術後, ほほ正常に回復 した. 4 年後, 両下肢のしびれが出現し，次第に歩行 困難となった。受傷後 6 年時に, MRI で脊䯣空洞症 が発見された。治療は Th12 から L2 の椎弓切除とSP shunt術を行い, 症状は改善し, 杖歩行が可能となっ た.

術後 5 年で両上肢のしびれが出現し, 徐々に上下肢 の筋力が低下し，筋萎縮が出現した。

33 歳時（受傷後 14 年）の MRI で, 空洞は多房性 で，脊髄円錐部から延髄，さらには第 4 脳室まで拡大 し，脊䯣実質は薄くなっていた（図 2-a，b）。空洞内 には多くの隔壁があり，多房性の空洞であった。S-P shunt tubeの腹腔遠位端を試験切開すると，大網の 瘉着により tube は閉塞していた。

再手術は, 頚椎（C3～6）の平林式脊柱管拡大術に

表 3 手術方法と治療成績

\begin{tabular}{|c|c|c|c|c|}
\hline 症例 & 手術方法 & 術後の空洞 & 症状の推移 & 追跡期間 \\
\hline \multicolumn{5}{|c|}{ 1. 初回 } \\
\hline & $S-P$ shunt & shunt 不全 & \multirow{2}{*}{ 再発·増悪 } & \multirow{2}{*}{8 年 } \\
\hline & $\begin{array}{l}\text { 椎弓切除術 } \\
\quad(\text { Th12 L L })\end{array}$ & 空洞増大 & & \\
\hline & 2 回目 & & \multirow[b]{2}{*}{$\begin{array}{l}\text { しびれ軽滅 } \\
\text { 麻㾝残存 }\end{array}$} & \multirow[b]{2}{*}{1.2 年 } \\
\hline & $\begin{array}{l}\text { S-S shunt } \longrightarrow \\
\text { C3 } \sim 6 \text { 拡大術 }\end{array}$ & ごく軽度縮小 & & \\
\hline 2 . & $\begin{array}{l}\text { S-S shunt } \\
\text { 椎弓切除術 } \\
\qquad \quad(\mathrm{Th} 7 \sim 8)\end{array}$ & $\begin{array}{r}\mathrm{Th} \text { - 著明縮小 } \\
\mathrm{C} \text {-軽度縮小 }\end{array}$ & 軽 隇 & 1.3 年 \\
\hline 3 & $\begin{array}{l}\text { S-S shunt } \\
\text { C3 } 2 \text { 拡大術 }\end{array}$ & 著明に縮小 & 軽 隇 & 1 年 \\
\hline & $\begin{array}{l}\text { S-S shunt } \\
\text { 椎弓切除術 } \\
\qquad(\text { Th10 - 11) }\end{array}$ & ほぼ消失 & 消 失 & 10 力月 \\
\hline
\end{tabular}




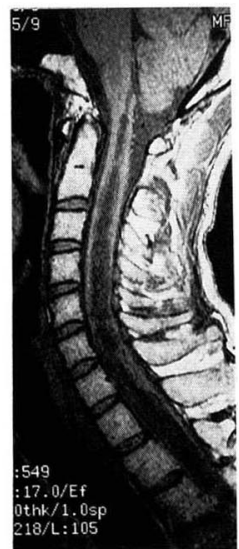

(a)

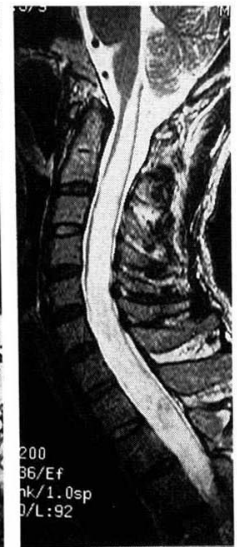

(b)

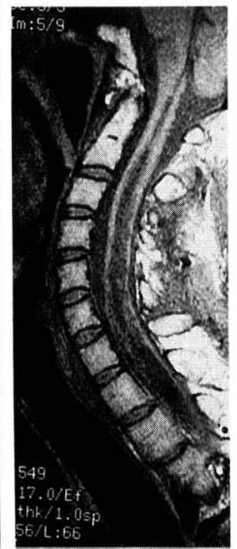

(c)

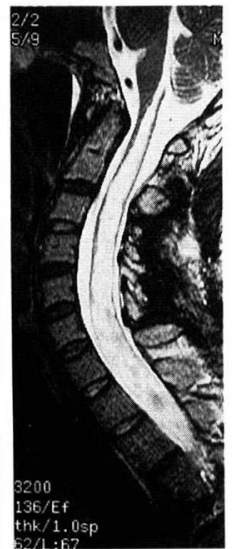

(d)

図 2 症例 $1: \mathrm{L}_{2}$ 破裂骨折後 14 年 再手術前 MRI （a） $\mathrm{T}_{1}$ 強調像,（b） $\mathrm{T}_{2}$ 強調像 術後MRI (c) $\mathrm{T}_{1}$ 強調像, (d) $\mathrm{T}_{2}$ 強調像 S-S shunt 術後 1 年時, 空洞はわずかに縮小したのみ.

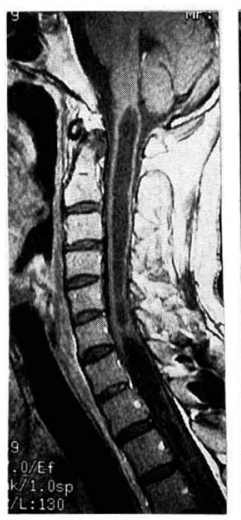

(a)

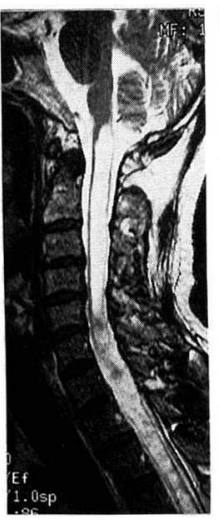

(b)

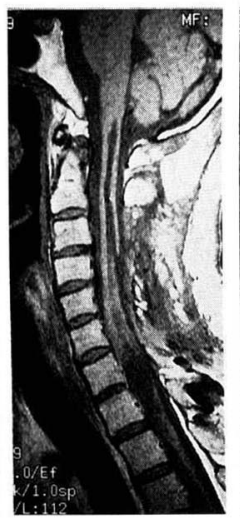

(c)



(d)

図 3 症例 $3: \mathrm{C}_{7} / \mathrm{Th}_{1}$ 椎間関節脱臼後 4 年

術前 MRI (a) $\mathrm{T}_{1}$ 強調像, (b) $\mathrm{T}_{2}$ 強調像

術後 MRI (c) $\mathrm{T}_{1}$ 強調像, (d) $\mathrm{T}_{2}$ 強調像

S-S shunt 術後 1 年時, 空洞は著明に縮小した.

よる腫大した脊䯣の除圧と S-S shunt 術を行った。 術後，MRIではわずかに空洞が縮小し（図 2-c，d）, 臨床的には上肢のしびれは軽減したが, 筋萎縮などの 麻㾝は残存した.

症例 $3: \mathrm{C} 7 / \mathrm{Th} 1$ 椎間関節脱臼 (完全麻疩), 男性

51 歳のとき交通事故による C7/Th1 間の椎間関節 脱臼で, 観血的整復術を施行され, 完全麻瘦であった. 2 年後より右上肢のしびれが出現し, MRI で空洞症
と診断された（図 3-a, b).

手術は C3 から 6 の脊柱管拡大術を行い, C4 高位 で脊髄切開を加え, シリコン製の S-S shunt tubeを 挿入し, 脊髄軟膜に固定した. 手術時, くも膜は高度 に白濁し, 肥厚していた. 腫大した脊髄は脊髄切開に より髄液が噴出し, 虚脱した.

術後の MRI で空洞は著明に縮小し, 症状はほほ消 失した（図 3-c, d). 
症例 4: L1 破裂骨折（完全麻痺）

18 歳のとき胴上げされて転落し，L1 破裂骨折，完 全麻痷となった。受傷後 25 年頃より, 左胸部の痛み が出現し, 知覚障害も出現した。 また, 左手尺側のし びれも出現した，症状は咳くくしゃみで増悪した. 29 年後の MRI で, 損傷部より中枢側に向けて C6 まで 多房性の空洞症が認められた（図 4-a, b).

手術は Th10１1 の椎弓切除と S-S shunt術を行っ た。くも膜は白濁, 肥厚し, 脊髄切開により髄液が噴 出し, 脊髄は虚脱した。

術後, 症状は消失し, MRI では shunt tube の先 端より中枢側で空洞は消失していた（図 4-c,d）.

\section{考察}

外傷性脊髄空洞症はまれなもので，その発生頻度は $1.2 \%^{1)}$ から $3.2 \%^{5)}$ 程度とされていた. しかし，近年 MRIにより空洞症の診断が容易となって，報告例は 増加傾向にあり, MRI を用いた研究では, 飛松ら は発生率 $8.3 \%$, Wang ら ${ }^{6)}$ は $25.5 \%$ と報告している.

本症の成因に関しては，これまでいくつかの説があっ たが, 最近では, くも膜癒着の合併による微細な髄液

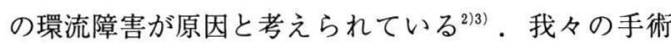
例全てにくも膜の白濁と肥厚が認められ，この説を示 唆するものと考えられる。

治療方法は, 最近では S-S shuntがS-P shuntよ
り閉塞しにくい点で優れていると言われている2. 我々 も S-P shunt術施行例で shunt 不全を経験したため, 現在ではS-S shuntを行っている.しかし， S-S shunt でも閉塞した報告 ${ }^{2) 4}$ があり, shunt 不全の課 題は現在も解決されていない. 大田ら ${ }^{4)}$ は S-S shunt 不全防止のために複数の tubing を薦めている.また, shunt 設置高位については, 上肢症状が強かった 2 例 ではまず脊柱管拡大術で腫大した脊髄の除圧をはか り, 次に空洞が最大の部分に脊䯣切開を加えて shunt tube を設置した．脊髄切開による新たな神経症状の 出現は経験していない. 損傷部の尾側で行った例では 頭側の空洞の縮小が不十分であったことより, shunt は損傷部の頭側に設置した方が有効と思われる.

本症の予後については，すでに筋萎縮がある症例で は脊髄の可塑性が失われており, もはや麻瘏の改善は 困難で，しびれおよび疼痛の改善が期待できるのみで あろう。早期に診断し, 症状進行時に時期を逸せずに 適切な処置を行うことが必要と考える。

$$
\text { ま と め }
$$

(1)外傷性脊䯣空洞症の 6 例を経験し, 診断と治療を 中心に検討した。

(2)初発症状は疼痛あるいはしびれであり，長期経過 例では高度の筋萎縮が出現していた。

(3) 4 例にS-S shunt 術を施行し, 空洞がほほ消失



(a)

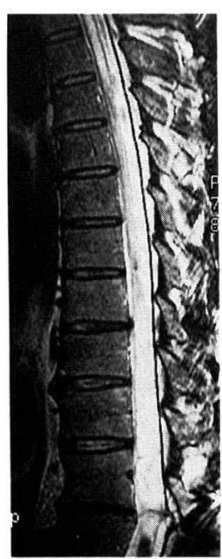

(b)

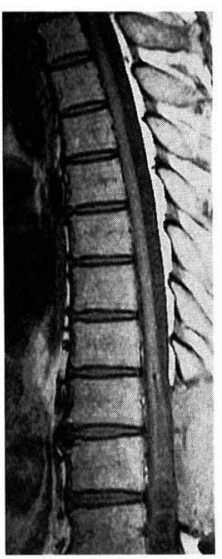

(c)

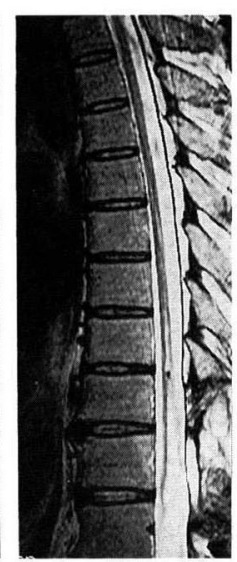

(d)

図 4 症例 $4: \mathrm{L}_{1}$ 破裂骨折後 29 年 術前 MRI (a) $\mathrm{T}_{1}$ 強調像, (b) $\mathrm{T}_{2}$ 強調像 術後 MRI (c) $\mathrm{T}_{1}$ 強調像, (d) $\mathrm{T}_{2}$ 強調像 S-S shunt術により shunt tube 先端より中枢側の空洞は消 失した。 
したものが 1 例, 著明な縮小が 2 例，わずかな縮小が 1 例であった。

(4)再手術の 1 例では脊髄は萎縮し, 麻痺か残存した.

\section{参 考 文 献}

1) Barnett, et al.: Syringomyelia, pp3-313, WB Sounders, London, 1973.

2）藤原桂樹ら：外傷後脊髄空洞症. 臨整外, 28 : 10231028, 1993

3）飛松治基ら：外傷性脊髄空洞症の経験. 日本パラプレ
ジア医学会誌, $5:$ 192-193, 1992

4）大田秀樹ら：外傷後脊髄空洞症に対する手術療法の検 討. 日本脊椎外科学会誌, $6: 28,1995$.

5) Rossier AB., et al.: Posttraumatic cervical syringomyelia. Brain, 108 : 439-461, 1985.

6) Wang, D., et al.: The spinal cord over 20 years following trauma-An MRI study of 153 patients. Programme and Abstracts 33rd Annual Scientific Meeting of the International Medical Society of Paraplegia : 113, 1994. 